\title{
Fatty acid composition and nutritional relevance of most widely consumed margarines in Spain
}

\author{
By Elvira Larqué ${ }^{1}$, Marta Garaulet ${ }^{1}$, Francisca Pérez-Llamas ${ }^{1 \star}$, Salvador Zamora ${ }^{1}$ and \\ F. Javier Tebar ${ }^{2}$
}

\author{
${ }^{1}$ Departamento de Fisiología. Universidad de Murcia. Campus Espinardo, 30100 Murcia. \\ Teléfono: +34-968-364942. Fax: +34-968-363963. E-mail: frapella@um.es \\ ${ }^{2}$ Servicio de Endocrinología. Hospital Virgen de la Arrixaca. Murcia, España.
}

\section{RESUMEN}

Composición en ácidos grasos de las margarinas de mayor consumo en España y su importancia nutricional.

Este estudio examina la composición de ácidos grasos de las margarinas de mayor consumo en España en el año 2000, incluyendo ácidos grasos trans. Todas las margarinas contenían al menos $20 \%$ de linoleico, siendo el contenido medio del $38 \%$. Los ácidos grasos saturados (laúrico y mirístico) no sobrepasaron el $4 \%$ del total de ácidos grasos. La mayoría de las margarinas contenían menos del $5 \%$ de ácidos grasos trans $C 18: 1$, aunque la variabilidad era elevada entre las distintas marcas (coeficiente de variación: $112 \%$ ), siendo la mediana del $2.5 \%$; los ácidos grasos trans poliinsaturados C18:2 y C18:3 no representaron más del $1 \%$. Índices nutricionalmente importantes como el cociente ácidos grasos saturados/insaturados, índices trombogénico y aterogénico, fueron menores de 0,5 . Los resultados sugieren que las margarinas españolas muestran un cambio hacia una distribución de ácidos grasos más saludable, aunque debido a la gran variabilidad en su composición, la información del etiquetado debe mejorar para evitar perturbaciones en la tradicional dieta Mediterránea de España.

PALABRAS-CLAVE: Ácidos grasos - Ácido linoleico - Cromatografía de gases - Índice de aterogenicidad - Índice de trombogenicidad - Isómeros trans - Margarinas.

\section{SUMMARY}

Fatty acid composition and nutritional relevance of most widely consumed margarines in Spain.

This study examines the fatty acid composition of margarines of major consumption in Spain in 2000. All the margarines contained at least $20 \%$ of linoleic acid, the average content of this fatty acid being $38 \%$. Saturated fatty acids (lauric and miristic acids) did not exceed $4 \%$ of the total fatty acid content. Most of the margarines analyzed contained less than $5 \%$ trans C 18:1, although this content varied greatly among margarines (coefficient of variation: 112\%) being median value 2.5\%; polyunsaturated trans $\mathrm{C} 18: 2$ and trans $\mathrm{C} 18: 3$ did not represent more than $1 \%$. Nutritionally important ratios like saturated/unsaturated fatty acids, thrombogenicity and atherogenicity indexes were lower than 0.5 . The findings suggest that Spanish margarines have moved to becoming products with a potentially healthier distribution of fatty acids. Even so, the great variability shown in fatty acid composition of margarines and poor labeling, highlight the importance of greater consumer information to avoid upsetting the traditional Mediterranean diet of Spain.

KEY-WORDS: Atherogenicity index - Fatty acids - Linoleic acid - Margarines - Trans isomers - Thrombogenicity index.

\section{INTRODUCTION}

The Mediterranean diet has been described as a useful model for providing recommended energy and nutrient levels for different population groups (Moreiras-Varela, 1989). Spain and most of the European Mediterranean countries show the lowest level of cardiovascular disease (CVD) mortality in Europe (Uemura and Pisa, 1988). Traditionally olive oil has been the main source of fat in the Mediterranean diet, although there has been a gradual increase in margarine and butter consumption during recent years. Although the direct consumption of margarine in Spain is still low (2 $\mathrm{g} /$ person/day), the intake of foods containing margarine in their composition (industrial bakery products, biscuits, etc.) is rising (Serra-Majem et al., 1993).

There has been controversy surrounding the safety of margarine. For example, it has been reported that margarine can safety be consumed in a prudent diet because it is a source of polyunsaturated fatty acids (PUFA), lacks cholesterol and contains a level of saturated fatty acids (SFA) lower than that of animal fat (Beare-Rogers et al., 1979). However, Willett et al. (1994) identified margarine as one of the major sources of trans fatty acids. Several epidemiological studies have shown an association between dietary trans fatty acids and CVD but these studies have been contradictory (Willet et al., 1993; Roberts et al., 1995; Fritsche et al., 1998). It is known that the nutritional quality of margarines depends on several factors: fat sources, manufacturing process, etc. To achieve the solid consistency necessary for margarines, manufacturers are permitted to blend the unmodified liquid oils with a small amount of natural solid fat or to hydrogenate some edible oils, which involves the formation of trans fatty acids (Bourr, 1985; Hernández and Boatella, 1986). Margarine industry has made great strides in making its products more heart-healthy and is leading the effort to reduce fat, saturated fat and trans fat (Michels and Sacks, 1995; Stender et al., 1995; Ovesen et al., 1996). However, in different countries the processes 
followed to achieve these goals have modified the nutritional characteristics of the products in different ways.

For these reasons, the aim of the present study was to evaluate the fatty acid composition of margarines widely consumed in Spain in the year 2000 and their propensity to influence the incidence of coronary heart diseases.

\section{MATERIAL AND METHODS}

\subsection{Sources and sample preparation}

Twelve brands of margarines widely consumed in Spain (O.C.U., 1999) were purchased from local suppliers in 2000. The products were from the following margarine-producing factories: Unilever food Spain S.A., Leioa, Spain; van Dijk Food Products, Lopik, Holland; Dia S.A., Getafe, Spain; Grupo Unigro S.A., Valladolid, Spain; Koninklijke Brinkers, Zeewalde, Holland. Samples of the same brand were bought and analyzed in May and again in September 2000, in order to observe differences between batches. Samples were stored under refrigeration $\left(4^{\circ} \mathrm{C}\right)$ until they were analyzed. Margarines were homogenized and each sample was analyzed twice.

\subsection{Analytical methods}

\section{Analysis of fatty acids}

Total lipids were extracted from the margarines with chloroform/methanol $(2: 1, \mathrm{v} / \mathrm{v})$ according to the method of Folch et al. (1957). Fatty acid methyl esters (FAME) were prepared with methanolic $\mathrm{HCl}$ $(1: 1)$ at $85^{\circ} \mathrm{C}$ for $1 \mathrm{~h}$ and dissolved in hexane (Stoffel et al., 1959). FAME of samples from the year 2000 were analyzed by gas-liquid chromatography (GLC) using a SP-2560 fused silica capillary column (100 m x $0.25 \mathrm{~mm}$ inner diameter, $20 \mu \mathrm{m}$ film thickness; Suppelco, Bellefonte, PA) in a Hewlett-Packard 5890 gas chromatograph (Hewlett-Packard, Avondale, PA). The oven temperature was programmed for 39 minutes at $175^{\circ} \mathrm{C}$ and was increased to $230^{\circ} \mathrm{C}$ at a rate of $3^{\circ} \mathrm{C}$ per minute and held for 14 minutes. Helium was used as the carrier gas at a pressure of $290 \mathrm{kPa}$. Peaks were identified by comparison with their retention times with appropriate FAME standards (Sigma Chemical Company, Urbana, IL). Finally, the double bond position of isomers were confirmed by GLC-mass spectrometry analysis of their 2-alkenyl-4,4-dimethyloxazoline (DMOX) derivatives (Zhang et al., 1988).

For GLC-mass spectrometry analysis, a VG Analytical MS System (Model 7070EQ, VG Analytical, Manchester, England), equipped with an $11 / 250$ data system interfaced to a Varian gas chromatograph (Model Vista 6000, Varian Associates, Palo Alto, CA) was operated at an ionization energy of $70 \mathrm{eV}$. GLC separation of the DMOX derivatives was performed on the same SP-2560 capillary column described for the FAME analysis. Helium was the carrier gas. The oven temperature was programmed from $140^{\circ} \mathrm{C}$ at $1.5^{\circ} \mathrm{C}$ per minute to $220^{\circ} \mathrm{C}$ and held for 15 minutes. For the final determination of the composition of the C18:1 isomers in margarines, the FAME were fractionated by silver-nitrate thin-layer chromatography and further GLC, to avoid the overlap of trans C18:1 (12-trans, 13-trans, 14-trans, 15-trans octadecenoic acid) with cis C18:1 isomer peaks (Ulberth and Henninger, 1992).

\section{Calculated Indices}

The saturated/unsaturated fatty acids (SFA/UFA) ratios were calculated including trans fatty acids in the UFA group. The atherogenicity (AI) and thrombogenicity (TI) indices were also calculated according to the following equations (Ulbricht and Southgate, 1991)

$A I=\left(a S^{\prime}+b S^{\prime \prime}+c S^{\prime \prime \prime}\right) /\left(d P+e M+f M^{\prime}\right)$, being $S^{\prime}=$ C12:0; $S^{\prime \prime}=C 14: 0 ; S^{\prime \prime \prime}=C 16: 0 ; P=$ sum of $n-6$ and n-3 families PUFA; $M=$ cis C18:1; $M$ ' = sum of the other monounsaturated fatty acids (MUFA); $b=4, a=$ $c=d=e=f=1$.

$\mathrm{TI}=\mathrm{mS}^{\mathrm{IV}} /(\mathrm{nM}+\mathrm{oM}+\mathrm{p}(\mathrm{n}-6)+\mathrm{q}(\mathrm{n}-3)+(\mathrm{n}-3 / \mathrm{n}-6)$, with $S^{\text {IV }}=$ sum of C14:0, C16:0 and C18:0; $(n-6)=$ sum of the $n-6$ family PUFA; $(n-3)=$ sum of the $n-3$ family PUFA; $M$ and $M^{\prime}=$ as in the previous equation; $\mathrm{m}=1 ; \mathrm{q}=3 ; \mathrm{n}=0=\mathrm{p}=0.5$.

\subsection{Statistical analysis}

The contents of the various fatty acids are given in $\mathrm{g}$ per $100 \mathrm{~g}$ total fatty acids. The coefficient of variation $(\mathrm{CV})$ was calculated in order to estimate the variability of each fatty acid among the different margarines analyzed. The median was estimated in order to identify the dispersion of data. To evaluate differences between batches a Two-way analysis of variance (ANOVA) considering brand of margarine and fatty acids was assayed. This analysis was followed by LSD test when the differences were significant.

\section{RESULTS}

The samples were analyzed in May and again in September 2000 in order to observe possible differences between batches. Table I shows the distribution of identified fatty acids (mean percentage of total fatty acid weight of each brand of margarine in both batches, and mean \pm SD and median of total margarines), as well as their aggregated values, SFA, MUFA, PUFA and total trans fatty acids. We did 
Table I

Fatty acid composition (\%) and indices of Spanish margarines in $2000^{*}$

\begin{tabular}{|c|c|c|c|c|c|c|c|c|c|c|c|c|c|c|}
\hline \multirow[b]{2}{*}{ Fatty acid ${ }^{* *}$} & \multicolumn{12}{|c|}{ Commercial margarines } & \multirow[b]{2}{*}{ Mean \pm SD } & \multirow[b]{2}{*}{ Median } \\
\hline & M1 & M2 & M3 & M4 & M5 & M6 & M7 & M8 & M9 & M10 & M11 & M12 & & \\
\hline C8:0 & 0.1 & 0.2 & 0.3 & $\operatorname{tr}$ & 0.1 & 0.1 & $\mathrm{Tr}$ & 0.2 & 0.1 & $\operatorname{tr}$ & 0.1 & 0.2 & $0.1 \pm 0.1$ & 0.1 \\
\hline $\mathrm{C} 10: 0$ & 0.3 & 0.3 & 0.4 & $\operatorname{tr}$ & 0.2 & 0.2 & 0.1 & 0.2 & 0.2 & $\operatorname{tr}$ & 0.2 & 0.3 & $0.2 \pm 0.1$ & 0.2 \\
\hline $\mathrm{C} 12: 0$ & 4.1 & 3.5 & 4.1 & $\operatorname{tr}$ & 2.1 & 2.4 & 0.1 & 2.3 & 3.9 & 0.1 & 1.2 & 4.5 & $2.4 \pm 1.7$ & 2.4 \\
\hline $\mathrm{C} 14: 0$ & 1.6 & 1.4 & 1.6 & 0.1 & 1.1 & 1.2 & 0.1 & 1.2 & 1.8 & 0.2 & 0.8 & 1.8 & $1.1 \pm 0.6$ & 1.2 \\
\hline $\mathrm{C} 16: 0$ & 12.3 & 11.2 & 12.4 & 11.4 & 18.7 & 21.7 & 7.1 & 21.7 & 16.3 & 12.9 & 16.8 & 16.0 & $14.9 \pm 4.5$ & 14.5 \\
\hline C17:0 & 0.1 & 0.1 & 0.1 & 0.1 & 0.1 & 0.1 & 0.1 & 0.1 & 0.1 & 0.1 & 0.1 & 0.1 & $0.1 \pm 0.0$ & 0.1 \\
\hline C18:0 & 8.6 & 8.4 & 10.0 & 5.1 & 4.6 & 4.3 & 15.5 & 3.2 & 7.4 & 7.4 & 4.6 & 6.1 & $7.1 \pm 3.4$ & 6.7 \\
\hline $\mathrm{C} 20: 0$ & 0.3 & 0.3 & 0.3 & 0.5 & 0.3 & 0.4 & 0.3 & 0.4 & 0.4 & 0.4 & 0.4 & 0.4 & $0.4 \pm 0.1$ & 0.4 \\
\hline $\mathrm{C} 22: 0$ & 0.3 & 0.5 & 0.4 & 0.2 & 0.5 & 0.3 & 0.7 & 0.2 & 0.4 & 0.4 & 0.3 & 0.3 & $0.4 \pm 0.1$ & 0.4 \\
\hline $\mathrm{C} 23: 0$ & $\operatorname{tr}$ & $\operatorname{tr}$ & 0.1 & $\operatorname{tr}$ & $\operatorname{tr}$ & 0.1 & $\operatorname{Tr}$ & $\operatorname{tr}$ & 0.1 & $\operatorname{tr}$ & $\operatorname{tr}$ & $\operatorname{tr}$ & $0.1 \pm 0.0$ & $\operatorname{tr}$ \\
\hline $\mathrm{C} 24: 0$ & 0.2 & 0.2 & 0.2 & 0.1 & 0.2 & 0.2 & 0.2 & 0.1 & 0.2 & 0.2 & 0.1 & 0.2 & $0.2 \pm 0.0$ & 0.2 \\
\hline C16:1 n-7 & 0.1 & 0.1 & 0.1 & 0.1 & 0.1 & 0.1 & 0.1 & 0.1 & ND & 0.1 & 0.1 & 0.1 & $0.1 \pm 0.0$ & 0.1 \\
\hline $\mathrm{C} 18: 1 \mathrm{t}$ & 0.1 & 0.1 & 1.0 & 18.6 & 0.1 & 0.1 & 3.1 & 0.1 & 6.7 & 16.4 & 3.1 & 6.4 & $4.6 \pm 6.5$ & 2.0 \\
\hline C18:1 n-9 & 19.7 & 20.6 & 19.2 & 28.3 & 25.6 & 25.3 & 20.9 & 27.7 & 24.2 & 26.7 & 34.2 & 25.2 & $24.8 \pm 4.3$ & 25.2 \\
\hline C18:1 n-x & 0.9 & 0.9 & 1.1 & 3.9 & 1.0 & 1.4 & 1.5 & 1.0 & 2.8 & 5.2 & 2.8 & 2.2 & $2.1 \pm 1.4$ & 1.5 \\
\hline $\mathrm{C} 20: 1 \mathrm{n}-\mathrm{9}$ & 0.1 & 0.1 & 0.1 & 0.2 & 0.2 & 0.2 & 0.1 & 0.2 & 0.1 & 0.1 & 0.6 & 0.2 & $0.2 \pm 0.1$ & 0.1 \\
\hline C18:2 n-6 & 47.7 & 49.4 & 45.3 & 30.0 & 42.9 & 36.4 & 49.5 & 38.6 & 30.8 & 26.1 & 27.9 & 33.2 & $38.2 \pm 8.5$ & 37.5 \\
\hline $\mathrm{C} 18: 2 \mathrm{ct}$ & 0.1 & 0.1 & 0.2 & 0.1 & 0.1 & 0.2 & 0.2 & 0.2 & 0.1 & 0.1 & 0.2 & 0.1 & $0.1 \pm 0.0$ & 0.1 \\
\hline $\mathrm{C} 18: 2 \mathrm{tc}$ & 0.1 & 0.1 & 0.1 & 0.1 & 0.1 & 0.1 & 0.1 & 0.2 & 0.1 & 0.1 & 0.1 & 0.1 & $0.1 \pm 0.0$ & 0.1 \\
\hline $\mathrm{C} 18: 2 \mathrm{tt}$ & ND & ND & ND & $\operatorname{tr}$ & ND & ND & $\operatorname{Tr}$ & ND & ND & tr. & $\operatorname{tr}$ & $\operatorname{tr}$ & $\operatorname{tr}$ & $\operatorname{tr}$ \\
\hline $\mathrm{C} 18: 2 \mathrm{i}$ & $\operatorname{tr}$ & $\operatorname{tr}$ & $\operatorname{tr}$ & 0.4 & ND & ND & 0.1 & tr & 0.2 & 0.6 & 0.1 & 0.2 & $0.1 \pm 0.2$ & $\operatorname{tr}$ \\
\hline C18:3n-6 & 0.1 & 0.1 & 0.1 & $\operatorname{tr}$ & 0.1 & 0.2 & $\operatorname{Tr}$ & 0.1 & 0.1 & 0.1 & 0.3 & 0.1 & $0.1 \pm 0.1$ & 0.1 \\
\hline C18:3n-3 & 3.0 & 2.2 & 2.6 & 0.7 & 1.6 & 4.5 & 0.2 & 1.9 & 2.9 & 2.5 & 5.5 & 2.2 & $2.5 \pm 1.5$ & 2.3 \\
\hline C18:3i & 0.1 & 0.1 & 0.1 & $\operatorname{tr}$ & 0.1 & 0.2 & $\mathrm{Tr}$ & 0.1 & 0.1 & 0.1 & 0.3 & 0.1 & $0.1 \pm 0.1$ & 0.1 \\
\hline \multicolumn{15}{|l|}{ Índices } \\
\hline SFA & 28.1 & 26.1 & 29.9 & 17.5 & 28.0 & 31.1 & 24.2 & 29.6 & 30.6 & 21.8 & 24.6 & 30.0 & $26.8 \pm 4.1$ & 28.0 \\
\hline MUFA & 21.0 & 21.9 & 21.6 & 51.1 & 27.1 & 27.2 & 25.7 & 29.3 & 33.9 & 48.6 & 41.0 & 34.0 & $31.9 \pm 10.2$ & 28.2 \\
\hline PUFA & 50.9 & 52.0 & 48.5 & 31.4 & 44.9 & 41.7 & 50.1 & 41.1 & 35.5 & 29.6 & 34.4 & 36 & $41.3 \pm 7.9$ & 41.4 \\
\hline Trans & 0.4 & 0.4 & 1.5 & 19.2 & 0.4 & 0.6 & 3.5 & 0.6 & 7.2 & 17.3 & 3.7 & 6.9 & $5.1 \pm 6.6$ & 2.5 \\
\hline
\end{tabular}

* Results are expressed in percentage ( $\mathrm{g}$ per100 $\mathrm{g}$ fatty acids), mean \pm standard deviation and median of total margarines from both batches. ND not detectable or tr trace amounts $(<0.1 \%)$.

${ }^{* *} \mathrm{c}$, cis ; t, trans; $\mathrm{n}-\mathrm{x}$, positional cis isomers; $\mathrm{i}$, other isomers. SFA, saturated fatty acids; MUFA, monounsaturated fatty acids (cis plus trans); PUFA, polyunsaturated fatty acids (cis plus trans); Trans (total trans fatty acids).

*** M1, Tulipán; M2, Flora; M3, Natacha; M4, Artúa; M5, Sonna; M6, Vegetal Día; M7, Girasol Día; M8, Maíz Día; M9, Ligeresa; M10, Super; M11, Holland; M12 Yogurina. 
not find significant differences in fatty acid composition between batches except in two brands, M11 and M12. The fatty acids with the highest differences between batches in the margarine M11 for the months of May and September respectively were the following: C12: 0.6 and 1.9\%; C18:1 trans: 6.0 and $0.1 \%$; C18:1 n-9:24.4 and 44.1\%; C18:2 n-6:35.2 and 20.5\%; C18:3 n-3: 3.9 and $7.1 \%$. In margarine M12: C12: 2.7 and 6.3\%; C18:1 trans: 10.1 and 2.7\%; C18:1 n-9: 27.3 and 23.1\%; C18:2 n-6: 32.0 and 34.4\%; C18:3 n-3: 1.7 and $2.6 \%$. The margarines analyzed were a rich source of PUFA, the mean content of these fatty acids being greater than those of SFA and MUFA (Table I). However, the $C V$ for these indices in all the brands analyzed was high: 15,32 and $19 \%$ for SFA, MUFA and PUFA, respectively.

The most abundant SFA (approximately $15 \%$ of the total fatty acids) was palmitic acid, while the atherogenic SFA (lauric and miristic acids) represented only about $4 \%$ of the total fatty acid content. The mean linoleic acid content was greater than $20 \%$ in all the margarines analyzed in 2000 (Table I).

The total trans fatty acid content varied greatly between the different brands of margarine (Table I) ( $C V=129 \%$ ) with M4 and M10 showing up to 30 times the levels found in M2 and M5. Because of the mean value is not very representative of a collective when the dispersion of the data is very high, we have calculated the median value for the fatty acids studied. Only trans fatty acids presented a median value $(2.5 \%)$ far away from the mean value $(5.1 \%)$. These total trans fatty acids were mainly trans $\mathrm{C} 18: 1$ type, while trans C18:2 and trans C18:3 polyunsaturated acids did not exceed $1 \%$ of the total fatty acids.

The derived ratios $n-6 / n-3$, SFA/UFA, Al, and TI of the margarines analyzed are reported in Table II. The SFA/UFA, Al and TI values were significantly low in all margarines, and below 0.5 in all cases.

\section{DISCUSSION}

Margarines have come a long way from the lard and tallow used in the late 1800 to the liquid fat blends and the introduction of hydrogenated fats in last years of the 20th century. Although some studies have pointed to a trend in the 90s to use "hard" type margarines (Annon, 1991; Ovesen et al., 1996; Ovesen et al., 1998), our study shows that the most widely consumed margarines in Spain in the present moment are semisoft and soft margarines, containing between $20-40 \%$ or more than $40 \%$

Table II

Nutritional ratios of margarines of major consumption in Spain*

\begin{tabular}{|c|c|c|c|c|}
\hline $\begin{array}{c}\text { Brand of } \\
\text { Margarine }\end{array}$ & $n-6 / n-3$ & SFA/UFA & Al & TI \\
\hline M1 & $15.80 \pm 0.41$ & $0.39 \pm 0.01$ & $0.32 \pm 0.00$ & $0.38 \pm 0.02$ \\
\hline M2 & $22.29 \pm 0.66$ & $0.36 \pm 0.01$ & $0.28 \pm 0.00$ & $0.33 \pm 0.01$ \\
\hline M3 & $17.13 \pm 0.90$ & $0.43 \pm 0.02$ & $0.33 \pm 0.00$ & $0.41 \pm 0.02$ \\
\hline M4 & $42.87 \pm 0.07$ & $0.21 \pm 0.00$ & $0.14 \pm 0.00$ & $0.19 \pm 0.00$ \\
\hline M5 & $26.25 \pm 3.88$ & $0.39 \pm 0.01$ & $0.35 \pm 0.01$ & $0.37 \pm 0.01$ \\
\hline M6 & $7.99 \pm 0.56$ & $0.45 \pm 0.01$ & $0.42 \pm 0.01$ & $0.51 \pm 0.00$ \\
\hline M7 & $293.05 \pm 56.38$ & $0.32 \pm 0.00$ & $0.10 \pm 0.01$ & $0.07 \pm 0.01$ \\
\hline M8 & $19.58 \pm 0.94$ & $0.42 \pm 0.00$ & $0.41 \pm 0.00$ & $0.44 \pm 0.00$ \\
\hline M9 & $11.21 \pm 1.20$ & $0.45 \pm 0.01$ & $0.40 \pm 0.02$ & $0.48 \pm 0.00$ \\
\hline M10 & $10.42 \pm 0.10$ & $0.28 \pm 0.00$ & $0.18 \pm 0.00$ & $0.37 \pm 0.00$ \\
\hline M11 & $5.77 \pm 2.83$ & $0.33 \pm 0.03$ & $0.28 \pm 0.00$ & $0.39 \pm 0.06$ \\
\hline M12 & $16.16 \pm 3.03$ & $0.43 \pm 0.11$ & $0.41 \pm 0.12$ & $0.43 \pm 0.09$ \\
\hline Total & $40.71 \pm 4.92$ & $0.37 \pm 0.01$ & $0.30 \pm 0.01$ & $0.36 \pm 0.00$ \\
\hline
\end{tabular}

\footnotetext{
* Results are expressed as mean \pm standard deviation margarines from both batches.

** M1, Tulipán; M2, Flora; M3, Natacha; M4, Artúa; M5, Sonna; M6, Vegetal Día; M7, Girasol Día; M8, Maíz Día; M9, Ligeresa; M10, Super; M11, Holland; M12 Yogurina.
} 
linoleic acid, respectively (Ovesen et al., 1996). None of the margarines analyzed was a hard margarine. This situation is not surprising, taking into account that in most of non Mediterranean countries the main cooking fat is margarine while in Spain, olive oil is the main source of cooking fat and margarine is usually used only as a spread.

Compared with the margarines sold in other European countries too, Spanish margarines are less solid. For example, the SFA/UFA index is lower (0.37) than that of Bulgarian (0.78) and Dutch (0.54) margarines (Tsanev et al., 1998), and the linoleic acid content is much higher than in Denmark (Ovesen et al., 1996, 1998). In fact, the high linoleic acid content of Spanish margarines means that this food might be considered a vehicle for the distribution of essential fatty acids (EFA). About half of the margarines from other Mediterranean countries (Kafatos et al., 1994) can be classified as hard with a linoleic acid content of less than $20 \%$. However, french margarines have a similar linoleic acid content to Spanish margarines (about 40\%) (Bayard and Wolff, 1995).

In general, the $\alpha$-linolenic acid content of both Greek $(0.9 \%)$ and French $(0.5 \%)$ margarines (Kafatos et al., 1994; Bayard and Wolff, 1995) is lower than that of Spanish margarines (2.5\%). In our study, the $n-6 / n-3$ index was much lower than that found in other Mediterranean countries (Kafatos et al., 1994; Bayard and Wolff, 1995). Only in one case (M7) the $n-6 / n-3$ index exceeded 200.

Although margarine is one of the most convenient and readily available sources of linoleic acid, the presence of large amounts of trans fatty acids detracts from its beneficial qualities. However, Spanish margarines present much lower levels of trans fatty acids (Table I) than the margarines of other industrialized countries: two to four times lower than in Canada (23.6\%) (Ratnayake et al., 1998), Greece (10\%) (Kafatos et al., 1994), New Zeeland (16.2\%) (Lake et al., 1996), and the United States (22.6\%) (Emken, 1995), and similar to the level observed in French tub margarines (Bayard and Wolff, 1995). Nevertheless, we, as well as other authors (Alonso et al., 2000) observed that the trans fatty acid content in spanish margarine varies considerably (range $=0.4-19.2 \%$ ). This finding has been also made in other countries (Aro et al., 1998). The mean content of trans-PUFA was very low (about $0.5 \%$ ), as was that of the trans C18:2 (9,12-trans, trans octadienoic acid), which is considered to be one of the most dangerous fatty acids from a health point of view (Kinsella et al., 1981). This fatty acid did not exceed $0.02 \%$, and was not found in seven of the margarines studied (Table I). The content of trans fatty acids found in our results (5.8\% mean value, median value $2.5 \%$ ) and similar studies (8.8\% mean value) (Alonso et al., 2000) were lower than the $16.8 \%$ detected in Spain in 1996 (Fernández San Juan, 1996). This results suggest a move towards lower trans fatty acid content in spanish margarine.

Many studies have indicated that high concentrations of linoleic acid tend to be associated with low concentrations of trans fatty acids (BeareRogers et al., 1979). This is confirmed by the present study, in which the margarines with a higher trans fatty acid content showed lower levels of linoleic acid (Table I). This is an important finding since several authors have pointed to the harmless nature of trans fatty acids in diets containing a sufficient amount of EFA (Zevenbergen et al., 1988).

The SFA, especially the short-chain fatty acids such as palmitic acid, lauric acid, and myristic acid raise blood cholesterol, (Mensink and Katan, 1992) although they probably do not have the same atherogenic potential as trans fatty acids (Hu et al., 1997). In our study, the level of these atherogenic SFA is below the one observed in other European countries (Ovesen et al., 1998; Kafatos et al., 1994) (Tables I and II).

Taken together, all these data suggest that present day Spanish margarines are healthier products than their counterparts sold in other countries. This affects their $\mathrm{Al}$ and $\mathrm{TI}$, two parameters which are widely used in foods to ascertain their health affecting potential. The mean Al calculated for the margarines was lower than the index obtained by our group for pork, rabbit, lamb, turkey, chicken and beef, and even for the fish analyzed (tuna, hake, sea bream and sardine) (Pérez-Llamas et al., 1998). This means that the fat quality of modern Spanish margarines is extremely acceptable. The TI, on the other hand, was generally three times higher than for the above mentioned meats and six times higher than that of the fish analyzed.

The wide variations observed in the margarines, not only as regards to their SFA, MUFA, PUFA, and trans fatty acids contents (Table I) but also to their TI, $\mathrm{Al}$, and SFA/UFA indices (Table II), point to their different propensities for influencing the incidence of coronary heart disease. The information offered to the consumer is totally inadequate. Only three of the margarines show the MUFA, PUFA and SFA data and only one mentions the trans fatty acid content (data not shown). None of the labels refers to the linoleic acid content so that not only is it impossible to know the EFA content but it is also not possible to classify the margarines into soft, semisoft or hard.

In summary, our results show that Spanish margarines have a healthier distribution of fatty acids than the margarines analyzed in other countries. The margarines as a whole are potentially less atherogenic than many widely consumed meat products. However, the variations seen between the most widely consumed margarines and the very bad labeling found in this 
study highlight the importance of informing the consumer in order to avoid upsetting the traditional Mediterranean diet that characterizes Spain.

\section{ACKNOWLEDGMENTS}

The authors thank Vanesa Paredes for her excellent technical assistance. We also thank Dr. Manuel Canteras from the Department of Biostatistic from the University of Murcia for the preparation of the manuscript.

\section{REFERENCES}

Alonso, L., Fraga, M.J. and Juarez, M. (2000) Determination of trans fatty acids and fatty acid profiles in margarines marketed in Spain. J. Am. Oil Chem. Soc., 77, 131-136.

Annon, G. (1991). Retail market share of margarines and spread products en National Association of margarine manufacters, p. 14-18, Washington DC.

Aro, A., van Amelsvoort, J., Becker, W., van Erp-Baart, M., Kafatosm A., Leth, T. and van Poppel, G. (1998) Trans fatty acids in dietary fats and oils from 14 European countries: the TRANSFAIR study. J. Food. Comp. Anal., 11, 137-149.

Bayard, C.C. and Wolff, R.L. (1995) Trans-18:1 acids in French tub margarines and shortenings: recent trends. J. Am. Oil Chem. Soc., 72, 1485-1489.

Beare-Rogers, J.L., Gray, L.M. and Hollywood, R. (1979) The linoleic acid and trans fatty acids of margarines. Am. J. Clin. Nutr., 32, 1805-1809.

Bourr, H. (1985) Los ácidos grasos poliinsaturados en la alimentación. Alimentaria, 161, 31-47.

Emken, E.A. (1995) Trans fatty acids and coronary heart disease risk: physicochemical properties, intake and metabolism. Am. J. Clin. Nutr., 62, 659S-669S.

Fernández San Juan, P.M. (1996) Study of isomeric trans fatty acids content in the commercial Spanish foods. Int. J. Food Sci. Nutr., 47, 399-403.

Folch, J., Lees, M. and Stanley, G.A. (1957) A simple method for the isolation and purification of total lipids from animal tissues. J. Biol. Chem., 226, 497-509.

Fritsche, J., Steinhart, H., Kardalinos, V. and Klose, G. (1998) Contents of trans fatty acids in human substernal adipose tissue and plasma lipids: relation to angiographically documented coronary heart disease. Eur. J. Med. Res., 18, 401-406.

Hernández, N. and Boatella, J. Grasas hidrogenadas: aspectos bromatológicos, Alimentaria, 178, 45-52.

Hu, F.B., Stampfer, J.E., Manson, E., Rimmm E., Colditz, G.A., Rosnerm B,A,, Hennekens, C.H. and Willet, W.C. (1997) Dietary fat intake and the risk of coronary heart disease in women. N. Engl. J. Med., 337, 1491-1499.

Kafatos, A., Chrysafidis, D. and Peraki, E. (1994) Fatty acids composition of Greek margarines. Margarine consumption by the population of Crete and its relationship to adipose tissue analysis. Int. J. Food Sci. Nutr., 45, 107-114.

Kinsella, J.E., Bruckner, Mai, J. and Shimp, J. (1981) Metabolism of trans fatty acids with emphasis on the effects of trans, trans-octadecadienoate on lipid composition, essential fatty acid, and prostaglandins: an overview. Am. J. Clin. Nutr., 34, 2307-2318.

Lake, R., Thomson, B., Devane, G. and Scholes, P. (1996) Trans fatty acid content of selected New Zealand foods. J. Food Comp. Anal., 9, 365-374.
Mensink, R.P. and Katan, M.B. (1992) Effects of dietary fatty acids on serum lipids and lipoproteins. Arterioscl. Thromb., 12, 911-919.

Michels, K. and Sacks, F. (1995) Trans fatty acids in European margarines. N. Engl. J. Med., 332, 541-542.

Moreiras-Varela, O. (1989) The Mediterranean diet in Spain. Eur. J. Clin. Nutr., 43, S83-S87.

O.C.U. (1999) Análisis de margarinas. Compra Maestra, 227, 4-9.

Ovesen, L., Leth, T. and Hansen, K. (1996) Fatty acid composition of Danish margarines and shortenings, with special emphasis on trans fatty acids. Lipids, 31, 971-975.

Ovesen, L., Leth, T. and Hansen, K. (1998) Fatty acid composition and contents of trans monounsaturated fatty acids in frying fats, and in margarines and shortenings marketed in Denmark. J. Am. Oil Chem. Soc., 75, 1079-1083.

Pérez-Llamas, F., López-Jiménez, J.A., Marín, J.F. and Zamora, S. (1998) Characteristics of the fat of some foods from the meats group and the relation with health status. Nutr. Hosp., 13, 95-98.

Ratnayake, W.M.N., Pelletier, G., Hollywood, R., Bacler, S. and Leyte, D. (1998) Trans fatty acids in Canadian margarines: recent trends. J. Am. Oil Chem. Soc., 75, 1587-1594.

Roberts, T.L., Wood, D.A., Riemersma, R.A., Gallagher P.J. and Lampe, F.C. (1995) Trans isomers of oleic and linoleic acids in adipose tissue and sudden cardiac death. Lancet, 345, 278-281.

Serra-Majem, L., Ribas, L., Lloveras, G. and Salleras, L. (1993) Changing patterns of fat consumption in Spain. Eur. J. Clin. Nutr., 47, S13-S20.

Stender, S., Dyerberg, J., Holmer, J., Ovesen, L. and Sandström, B. (1995) The influence of trans fatty acids on health. Clin. Sci., 88, 375-392.

Tsanev, R., Russeva, A., Rizov, T. and Dontcheva, I.V. (1998) Content of trans fatty acids in edible margarines. J. Am. Oil. Chem. Soc., 75, 143-145.

Uemura, K and Pisa, Z. (1988) Trends in cardiovascular disease mortality in industrialized countries since 1950. Wld. Hlth. Stat. Q., 41, 155-178.

Ulberth, F. and Henninger, M. (1992) Simplified method for the determination of trans monoenes in edible fats by TLC-GLC. J. Am. Oil Chem. Soc., 69, 829-831.

Ulbricht, T.L.V. and Southgate, D.A.T. (1991) Coronary heart disease: seven dietary factors. Lancet, 338, 985-992.

Willett, W.C., Stampfer, M.J., Manson, J.E., Colditz, G.A., Speizer, F.E., Rosner, B.A., Sampson, L.A. and Hennekens, C.H. (1993) Intake of trans fatty acids and risk of coronary heart disease among women. Lancet, 341, 581-585.

Willet, W.C. and Ascherio, A. (1994) Trans fatty acids: are the effects only marginal?. Am. J. Public Health, $\mathbf{8 4}$ $722-724$.

Zevenbergen, J.L., Houtsmuller, U.M.T. and Gottenbos, J.J. (1988) Linoleic acid requirement of rats fed trans fatty acids. Lipids, 23, 178-186.

Zhang, J.Y., Yu, Q.T., Liu, B.N. and Huang, Z.H. (1988) Chemical modification in mass spectrometry IV 2-alkenyl-4,4-dimethyloxazolines as derivatives for the double bound. Mass Spectr. Environ. Med., 25, 234-241. 